\title{
Analisis Alternatif Kebijakan Perikanan dalam Meningkatkan Pendapatan Nelayan di Kabupaten Konawe
}

\author{
Indrawan Tobarasi', Rahmanuddin Tomalili ${ }^{2}$ \\ ${ }^{1}$ Universitas Lakidende, ${ }^{2}$ Universitas Lakidende \\ Email: indrawan.t2684@gmail.com
}

\begin{abstract}
Abstrak: Penelitian ini menganalisis berbagai faktor yang mempengaruhi pendapatan nelayan di kabupaten konawe dengan mempertimbangkan potensi dan kondisi masyarakat setempat sehingga dapat dilakukan pemetaan untuk menganalisis alternatif kebijakan yang tepat untuk meningkatkan pendapatan nelayan. Penelitian ini menggunakan metode kualitatif dengan pendekatan deskriptif untuk melihat faktorfaktor yang mempengaruhi pendapatan nelayan. Data penelitian bersumber dari hasil wawancara terhadap stakeholder dan data sekunder dari berbagai literatur. Hasil penelitian menunjukan bahwa kondisi armada dan alat tangkap ikan yang belum memadai, terbatasnya modal kerja nelayan untuk memenuhi kebutuhan operasional tangkap, dan terbatasnya akses terhadap jaringan pemasaran hasil tangkap sangat mempengaruhi pendapatan nelayan di Kabupaten Konawe. Berdasarkan permasalahan tersebut maka alternatif kebijakan perikanan dapat dibuat pemerintah daerah untuk meningkatkan pendapatan nelayan di kabupaten konawe, antara lain: (1) Pengembangan modernisasi teknologi bagi nelayan melalui bantuan program modernisasi/ motorisasi alat tangkap, dan penyelenggaraan kegiatan penyuluhan teknologi dan pembinaan keterampilan, (2) Pengembangan sistem permodalan bagi nelayan melalui program bantuan permodalan bagi nelayan; dan (3) Pembentukan dan pengembangan sistem jaringan pemasaran melaui pembangunan pelabuhan pendaratan ikan (PPI) dan pembentukan tempat pelelangan ikan disekitar desa nelayan.
\end{abstract}

Kata Kunci: Analisis Kebijakan, Alternatif Kebijakan, peningkatan pendapatan nelayan.

Abstract: This study analyzed various factors that influence the income of fishermen in Konawe district by considering the potential and condition of the local community so that mapping can be done to analyze the right alternative policies to increase fishermen income. This study used a qualitative method with a descriptive approach to explore any factors that influence fishermen's income. Research data sourced from the results of interviews with stakeholders and secondary data from various literature. The results showed that the condition of the fleet and fishing gear were inadequate, the limited working capital of fishermen to meet the operational needs, and the limited access to the marketing network of fishing results greatly affected the income of fishermen in Konawe Regency. Based on these problems, alternative fisheries policies can be made by the local government to increase the income of fishermen in Konawe Regency, that are: (1) Development of technology modernization for fishermen through the assistance of the modernization/motorization of fishing gear programs, and the implementation of technology counseling and skills training activities; (2) Development of a capital system for fishermen by a capital assistance program for fishermen; and (3) Establishment and development of a marketing network system by construct of a fish landing port (PPI) and the establishment of a fish auction area around a fishing village.

Keywords: Policy Analysis, Alternative Policy, increasing fishermen's income. 


\section{Pendahuluan}

Pelaksanaan otonomi daerah dapat menjadi salah satu instrumen dalam peningkatan lajunya pertumbuhan kesejahteraan masyarakat di Indonesia apabila pembangunan di daerah mengacu pada potensi daerah atau geografis, dengan melaksanakan prinsip standar pelayanan minimal yang dilaksanakan oleh pemerintah daerah yang menjamin peningkatan mutu pelayanan masyarakat secara merata sehingga kesejahteraan masyarakat menjadi semakin baik (Surkati, 2012) dan berimbas pada pengurangan angka kemiskinan, sebab persoalan kemiskinan telah menjadi agenda utama pemerintah dan tersebar pada pada hampir seluruh elemen atau kelompok masyarakat dan salah satunya adalah kelompok masyarakat nelayan.

Berbagai kebijakan perikanan yang dilakukan oleh pemerintah ternyata belum mampu menangani persoalan kemiskinan nelayan saat ini. Kebijakan moneter dan fiskal yang diterapkan pemerintah selama ini belum cukup mendorong kemajuan sektor kelautan dan perikanan salah satu penyebabnya adalah tingkat suku bunga untuk usaha perikanan di Indonesia masih tergolong tinggi. Kondisi ini jelas sangat berbeda jauh dibanding negara-negara lain. Jepang misalnya, tingkat suku bunga yang diberlakukan untuk sektor perikanan hanya tiga persen per tahun, Malaysia melalui Bank Pertaniannya hanya membebankan bunga 1-3 persen pertahun, Thailand dan Australia hanya 39 persen per tahun, sementara Indonesia berada jauh diatas angka-angka tersebut (bunghatta.ac.id, 2018).

Masyarakat nelayan di Indonesia merupakan kelompok yang dihadapkan pada kompleksitas permasalahan ekonomi. Kemiskinan telah melekat erat pada kelompok-kelompok ini terutama bagi nelayan kecil (Winarno, 2011:6). Berbeda dengan nelayan modern yang acapkali mampu merespon perubahan dan lebih kenyal dalam menyiasati tekanan perubahan dan kondisi over fishing, nelayan kecil yang umumnya bersifat tradisional seringkali mengalami proses marginalisasi dan menjadi korban dari program pembangunan dan modernisasi perikanan yang sifatnya a historis (Indriyani, dkk, 2017).

Untuk menyelesaikan persoalan kesejahteraan nelayan di daerah, sebenarnya pemerintah daerah mempunyai wewenang dan tanggung jawab menyelenggarakan kepentingan masyarakat melalui berbagai kebijakan di bidang perikanan. Prinsip dasar pemberian otonomi dimaksud didasarkan atas pertimbangan bahwa daerah lah yang lebih mengetahui kebutuhan dan standar pelayanan bagi masyarakat di daerahnya. Atas dasar pertimbangan ini, maka pemberian otonomi diharapkan akan lebih mampu memacu pertumbuhan ekonomi dan kesejahteraan masyarakat pada akhirnya, dan pemerintah daerah diharapkan dapat memanfaatkan peluang dan mencari terobosan melalui berbagai kebijakan yang tepat untuk meningkatkan pendapatan masyarakat sehingga dapat meningkatkan kesejahteraan masyarakat khususnya masyarakat nelayan.

Kesenjangan antara semangat pelaksanaan otonomi daerah dan fenomena kemiskinan masyarakat nelayan sebagaimana penjelasan di atas tentu membutuhkan penjelasan agar bisa menguraikan dan menjelaskan berbagai penyebab terjadinya kesenjangan tersebut beserta solusi kebijakan yang tepat untuk 
menangani masalah itu. Sejauh ini studi mengenai kebijakan peningkatan kesejahteraan nelayan telah dilakukan antara lain tentang penerapan kebijakan sekaya maritim dalam rangka peningkatan kesejahteraan nelayan (Indriyani dkk, 2017). Hasil penelitian menunjukkan bahwa salah satu upaya untuk meningkatkan kesejahteraan nelayan adalah dengan pemberian bantuan selain untuk pemenuhan kebutuhan nelayan seperti bantuan rumah, alat tangkap, dan kapal nelayan, diperlukan juga bantuan yang bersifat investasi jangka panjang dan berkelanjutan, seperti pengembangan sarana dan prasarana pengolahan hasil melaut dan pengembagan akses pemasaran hasil perikanan. Demikian juga dengan analisis kebijakan peningkatan kesejahteraan nelayan kabupaten administrasi kepulauan seribu yang dilakukan oleh Karunia (2009) yang menyimpulkan bahwa salah satu faktor yag berpengaruh terhadap kesejahteraan nelayan adalah aspek kelembagaan yang kuat terhadap program-program pemerintah pada sektor perikanan dan kelautan.

Berbagai strategi kebijakan telah dibuat oleh pemerintah daerah dalam upaya peningkatan pendapatan nelayan, salah satu program yang dilakukan pemerintah daerah untuk meningkatkan pendapatan nelayan adalah dengan melakukan memfasilitasi pembuatan sertifikat nelayan, penyediaan sarana dan prasarana nelayan, serta melakukan bimbingan dan pendampingan kepada nelayan (Fathoni, 2015), selain itu, keberhasilan kebijakan pemerintah daerah dalam meningkatkan pendapatan dan kesejahteraan nelayan juga harus disesuaikan dengan pertimbangan aspek perilaku dan nilai-nilai yang ada pada msyarakat nelayan itu sendiri (Mamentu, 2015).

Artikel ini membahas tentang analisis alternatif kebijakan perikanan dalam meningkatkan pendapatan nelayan di Kabupaten Konawe. Penelitian ini berupaya menganalisis dan memetakan berbagai faktor-faktor yang mempengaruhi pendapatan nelayan di kabupaten konawe dengan mempertimbangkan potensi dan kondisi masyarakat setempat, sehingga dapat dilakukan pemetaan untuk menganalisis alternatif kebijakan yang tepat untuk meningkatkan pendapatan nelayan di Kabupaten Konawe berdasarkan pemetaan terhadap faktor-faktor yang mempengaruhi pendapatan nelayan.

\section{Metode Penelitian}

Penelitian ini merupakan penelitian kualitatif dengan menggunakan pendekatan deskriptif. Penelitian dilaksanakan di tiga desa, yaitu Desa Bokori, Desa Mekar, dan Desa Saponda, di Kecamatan Soropia Kabupaten Konawe Provinsi Sulawesi Tenggara. Ketiga desa ini adalah desa dengan penduduk mayoritas nelayan di Kabupaten Konawe. Teknik pengumpulan data dilakukukan melalui observasi lapangan, wawancara terhadap informan, baik wawancara mendalam (in-depth interview) maupun wawancara dalam bentuk group interview; dan studi dokumen terhadap beberapa dokumen laporan pemerintah kecamatan maupun pemerintah desa yang berhubungan dengan topik penelitian. Informan dalam penelitian ini terdiri atas Kepala dinas Kelautan dan Perikanan Kabupaten Konawe dan seorang staf, Unsur pemerintah kecamatan Soropia yakni Camat dan staf, Kepala desa dan 
Ketua BPD serta warga masyarakat desa (nelayan).

Proses penelitian dimulai dengan observasi lapangan sekaligus melakukan wawancara guna menidentifikasi permasalahan (Agenda Setting) yang berkaitan dengan faktor-faktor yang mempengaruhi pendapatan nelayan di Kabupaten Konawe berdasarkan data yang diperoleh dilapangan. Proses identifikasi masalah mengacu pada model analisis problem structuring guna menemukan masalah kebijakan (policy problems) melalui 4 (empat) fase sebagaimana dikemukakan oleh Dunn (1999), yaitu: pencarian masalah (problem search), pendefinisian masalah (problem definition), spesifikasi masalah (problem sfecification), dan pengenalan masalah (problem sensing), dan selanjutnya memformulasikan alternatif kebijakan (policy formulation) perikanan yang tepat untuk meningkatkan pendapatan nelayan di Kabupaten Konawe.

\section{Hasil Penelitian dan Pembahasan}

\section{a. Hasil Tangkap dan Pendapatan Nelayan di Kabupaten Konawe}

Berdasarkan temuan dilapangan, tingkat pendapatan nelayan di desa bokori, mekar dan saponda sangat dipengaruhi oleh mekanisme pemasaran dari hasil tangkap tersebut. Umumnya hasil tangkap nelayan di desa Bokori, Mekar dan Saponda menjual hasil tangkap mereka kepada tengkulak, karena sejak awal biasanya para nelayan sudah diberikan modal awal (panjar) oleh para tengkulak dengan komitmen semua hasil tangkapan akan diserahkan (dijual) kepada tengkulak yang bersangkutan.
Melalui sistem penjualan hasil tangkap kepada tengkulak ini ternyata telah menyebabkan kesenjangan distribusi pendapatan diantara nelayan yang ada di Kabupaten Konawe. Eksploitasi sumberdaya yang terjadi telah mengakibatkan nelayan miskin senantiasa berada dalam ketergantungan (tidak mandiri). Sistem penjualan kepada tengkulak terpaksa dilakukan oleh sebagian besar nelayan karena tidak ada Pangkalan Pelelangan Ikan (PPI) atau pasar khusus penjualan ikan di Kecamatan Soropia. PPI berada di Kecamatan Lalonggasumeeto dan dan di Kota Kendari yang jarak keduanya terbilang cukup jauh dari soropia. Sebagian kecil nelayan yang memiliki fasilitas ukuran perahu memadai terkadang membawa hasil tangkapan mereka ke PPI kendari, dan sebagiannya dijual secara lokal di dalam desa.

Rendahnya/ketimpangan distribusi pendapatan nelayan sebagai masalah utama dari permasalahan yang dihadapi khususnya pada sektor perikanan tersebut, sesungguhnya bersumber pada masalah substansi yaitu adanya sekelompok anggota masyarakat (nelayan miskin) yang secara struktural tidak mempunyai peluang dan kemampuan yang memadai untuk mencapai tingkat hidup yang layak. Akibatnya nelayan miskin tersebut harus mengakui keunggulan kelompok masyarakat lainnya dalam persaingan mencari nafkah dan pemilikan aset usaha (produktif), sehingga semakin lama semakin tertinggal. Meskipun sesungguhnya hasil produksi tangkapan ikan nelayan di tiga desa studi relatif meningkat setiap tahunnya.

Hasil tangkapan ikan yang diperoleh nalayan di tiga desa studi tersebut dipasarkan secara lokal dan antar daerah. Untuk pemasaran lokal nelayan 
menjual kepada pedagang pengumpul/tengkulak.

Kemudian pedagang pengumpul menjual ke pedagang pengecer dan terus ke konsumen, tetapi ada juga pedagang pengumpul yang langsung kepada konsumen. Sedangkan untuk pemasaran antar daerah biasanya dilakukan oleh pedagang pengumpul lokal dan selanjutnya dijual kepada pengumpul di luar daerah. Namun pada keadaan tertentu nelayan langsung menjual kepada pedagang pengumpul luar daerah. Hal ini terjadi apabila nelayan mengadakan penangkapan ikan jauh dari pangkalan dan pulang setelah delapan sampai sepuluh hari (satu bintang) melakukan operasi penangkapan. Harga ikan yang dijual kepada tengkulak antara satu nelayan dengan nelayan lain kadangkadang tidak sama, hal ini tergantung penilaian mutu ikan tersebut oleh tengkulak. Penentuan harga pada umumnya lebih banyak ditentukan oleh para tengkulak dan dibayar secara tunai.

Pendapatan nelayan yang berada di Desa Bokori dan Mekar dan Saponda juga beragam. Secara pasti sangat sulit untuk ditentukan karena mereka hanya mengatakan kira-kira. Salah satu penyebabnya sulit menghitung penghasilannya ialah karena mereka tidak terbiasa untuk menghitungnya. Keseluruhan hasil yang diperoleh biasanya mereka bawa ke tengkulak, tengkulaklah yang akan menentukan berapa jumlah yang akan dibayar. Akan tetapi berdasarkan hasil wawancara, diperoleh informasi bahwa pendapatan nelayan tersebut berkisar pada Rp. 1.000.000,sampai Rp. 2.500.000,- perbulannya.

Nelayan yang memiliki pendapatan di bawah Rp. 1.000.000,- perbulan merupakan nelayan yang tidak memiliki armada/alat, dimana mereka hanya sebagai buruh nelayan. Pendapatan mereka diperoleh melalui sistem pembagian hasil yakni $2 / 3$ merupakan bagian pemilik kapal dan $1 / 3$ bagian untuk buruh nelayan/ABK dan ada juga dengan cara menggaji buruh nelayan /ABK Rp. 30.000,- per hari. Sehingga para nelayan tersebut harus mencari mata pencaharian tambahan untuk menambah pendapatan keluarganya seperti petani, buruh tani dan pedagang.

\section{b. Faktor-Faktor} mempengaruhi yang Nelayan di Kabupaten Konawe

Dalam memahami berbagai permasalahan yang menjadi faktor yang mempengaruhi peningkatan pendapatan nelayan di Kabupaten Konawe, maka dilakukan proses indentifikasi permasalahan (agenda setting) yang menurut Dunn (1999:24) melalui 4 (empat) fase yang mendasarinya, yaitu: pencarian masalah (problem search), pendefinisian masalah (problem definition), spesifikasi masalah (problem sfecification), dan pengenalan masalah (problem sensing). Dan hasil identifikasi permasalahan berdasarkan data temuan di tiga desa studi diketahui bahwa penyebab masalah (Couse of Problem) yang menjadi faktor-faktor yang mempengaruhi pendapatan nelayan di Desa Bokori, Mekar dan Saponda adalah sebagai berikut:

\section{Terbatasnya Akses terhadap jaringan Pemasaran}

Hasil tangkapan nelayan biasanya dijual dalam bentuk ikan segar (80\%) dan Sebagian kecil (20\%) hasilnya untuk konsumsi sendiri. Agar ikan tetap segar maka nelayan melakukan penanganan dengan sistem pengesan dalam cold box yang sudah tersedia di kapal. Sebagian 
kecil ada juga nelayan yang mengolah hasil tangkapan untuk dijadikan kerupuk ikan/udang. Usaha ini bersifat usaha skala kecil (rumah tangga) dan dipasarkan hanya terbatas bagi penduduk setempat. Di samping itu juga pernah dilakukan pembuatan abon ikan, tetapi karena keterbatasan modal, usaha ini tidak bisa dilanjutkan.

Hasil tangkapan ikan yang ada di desa bokori dijual kepada para tengkulak yang berasal dari kecamatan soropia atau dari kota kendari. Sedangkan pemasaran hasil produksi usaha perikanan yang ada di desa mekar dan saponda adalah selain menjual kepada tengkulak dari kecamatan dan kota kendari, ada juga yang langsung menjual kepada pengumpul yang berasal dari desa setempat. Tetapi sesungguhnya pedagang pengumpul yang membeli hasil kepada nelayan juga merupakan perpanjangan tangan dari pada tengkulak.

Peran tengkulak terutama dalam pemasaran perikanan cenderung monopolistis yang mampu menentukan tingkat harga di tingkat produsen. Hasil tangkapan ikan yang dijual kepada pedagang pengumpul dibayar dengan cara tunai, tetapi kadang-kadang ada juga sebagian nelayan yang mendapat bayaran setelah beberapa trip baru menerima bayaran, yang terpenting bagi nelayan adalah setiap mereka turun ke laut bahanbahan kebutuhan sehari-hari bisa diperoleh langsung dari tengkulak. Dalam konteks ini, umumnya nelayan di desa bokori, mekar dan saponda telah memiliki kesepakatan awal dengan tengkulak tertentu yang terkait kesepakatan kepada siapa ikan hasil tangkapan akan dijual. Biasanya dengan kesepakan ini para nelayan mendapatkan upah atau bayaran uang muka lebih awal dari tengkulak sebelum turun ke laut sebagai bentuk kesepakatan tadi. Dengan kondisi tersebut, sesungguhnya mereka mempunyai keinginan untuk lepas dari sistem pasar ini namun hingga saat ini belum dapat diatasi. Untuk mendapatkan harga yang lebih, bagi nelayan yang tidak terikat oleh tengkulak terkadang menjual hasil tangkapannya di tengah laut kepada konsumen lokal ataupun nelayan luar.

Salah satu solusi bagi nelayan untuk keluar dari monopoli tengkulak, adalah menjual hasil tangkap ikan mereka secara langsung ke pelabuhan pelalangan ikan (PPI). Namun PPI yang ada di Konawe terletak di kecamatan lalonggasu meeto yang berjarak sekitar $20 \mathrm{~km}$ dari desa bokori dan mekar, dan lebih jauh lagi dari desa saponda. Akibat jarak ke PPI yang relatif jauh dan membutuhkan biaya dan waktu tambahan untuk sampai ke PPI maka nelayan lebih memilih untuk menjual hasil tangkapan mrk ke tengkulak. Selain itu, tidak tidak adanya pasar ikan di salah satu desa studi juga menjadi alasan nelayan untuk lebih memilih menjual hasil tangkap mereka kepada tengkulak.

\section{Terbatasnya Teknologi Penangkapan Ikan}

Armada perikanan merupakan salah satu faktor yang ikut mempengaruhi keberhasilan suatu penangkapan, selain itu alat tangkap dan musim juga sangat mempengaruhi. Nelayan di desa bokori, mekar dan saponda memiliki ciri khas tenaga yang terbatas dan peralatan yang sederhana. Meskipun terkadang telah menggunakan perahu motor bantuan pemerintah, akan tetapi mereka tetap menerapkan teknologi tradisional untuk penangkapan ikan. Dengan ciri khas yang demikian, daya saing mereka lebih rendah dibanding nelayan yang lebih kuat (Nelayan pemilik/pengusaha). 
Sehubungan hal tersebut, adapun armada perikanan yang dipergunakan oleh nelayan di desa bokori, mekar dan saponda dalam melakukan operasi penangkapannya juga masih bersifat tradisional, sesuai dengan alat tangkap yang mereka gunakan, yaitu: sampan dayung dan perahu motor. Sampan dayung digunakan oleh nelayan untuk melakukan penangkapan dengan alat gombang, pengerih, dan ambai di perairan yang tidak terlau jauh, jaring digunakan di perairan bagian luar, sedangkan perahu motor digunakan untuk melakukan operasi penangkapan dengan alat jaring (gill net), jaring kurau, dan rawai di sekitar laut banda.

Untuk setiap armada penangkapan di antara nelayan tersebut ada yang memiliki 2-3 jenis alat tangkap. Pada umumnya nelayan yang melakukan penangkapan ikan dengan menggunakan kapal motor alat penangkapan utama mereka adalah gill net (jaring hayat). Armada penangkapan yang dipergunakan nelayan di Desa Bokori, mekar dan saponda umumnya adalah perahu sampan dan kapal motor dengan ukuran panjang 14-20 meter, lebar 3-18 meter, dalam 11,5 meter dan ukuran kapal 2-10 GT. Kapal motor ini dilengkapi oleh tenaga penggerak berupa mesin diesel dengan kekuatan 4 - 24 PK. Harga kapal motor antara Rp. 10.000.000 - Rp. 20.000.000. Harga mesin antara Rp. 5.000.000 - Rp. 15.000.000. Jangkauan operasi dengan kapal ukuran 2 - $10 \mathrm{GT}$ ini adalah 2 - $8 \mathrm{mil}$ dari garis pantai.

Umumnya nelayan yang ada di desa bokori, mekar dan saponda masih menggunakan perahu sampan dan perahu motor ukuran kecil, kalaupun ada nelayan yang menggunakan perahu motor dengan kapasitas besar biasanya hanya kalangan tertentu yang merupakan nelayan pemilik atau pengusaha dari kalangan pengumpul yang ada di ketiga desa studi, namun jumlah nelayan seperti ini sangat sedikit.

3. Terbatasnya Permodalan Bagi Nelayan Modal merupakan salah satu faktor utama yang mempengaruhi pendapatan nelayan di kabupaten konawe. Peningkatan pendapatan nelayan akan berbanding lurus dengan peningkatan hasil tangkap, dan untuk meningkatkan hasil tangkap dibutuhkan armada serta biaya operasional tangkap dan biaya pemeliharaan armada yang relatif besar. Modal tetap yang ditanamkan oleh nelayan terdiri dari; pembelian mesin, kapal, jaring, rawai, gombang, pengerih, ambai, tali, cincin, lampu, bak es, senter, tong ikan, bahan bakar, serta biaya pemeliharaan kapal dan alat-alat tangkap.

Dari hasil penelitian ditemukan bahwa akses modal yang pernah diberikan pemerintah hanya dinikmati oleh nelayan pengusaha (tengkulak) saja. Hal ini disebabkan oleh faktor kedekatan, hubungan/relasi dan informasi yang dimiliki oleh tengkulak yang lebih luas dibanding dengan nelayan buruh. Pengalaman terhadap mandat permodalan melalui Keppres Nomor 39 Tahun 1980 maupun melalui Inpres Nomor 10 Tahun 1981, ternyata juga menjadikan usaha untuk mendapatkan modal menjadi sulit. Sampai saat ini, belum ada lembaga bantuan modal yang didirikan pemerintah daerah kabupaten untuk memberikan pelayanan bantuan atau pinjaman modal kepada nelayan. Bahkan dana desa di tiga desa studi belum di porsikan untuk memenuhi permodalan operasional bagi para nelayan. Kondisi tersebut akhirnya menyebabkan nelayan mencari jalan yang lebih cepat, yaitu meminjam pada nelayan kaya (tengkulak) yang ada. 


\section{c. Alternatif Kebijakan Peningkatan Pendapatan Nelayan di Kabupaten Konawe}

Dengan memperhatikan faktorfaktor yang mempengaruhi peningkatan pendapatan nelayan di kabupaten konawe, selanjutnya untuk melakukan spesifikasi permasalahan menjadi formal problem yang juga merupakan goal policy, maka akan digunakan teknik hirarkis pencarian masalah dalam bentuk diagram masalah seperti gambar berikut. Analisis dilakukan dengan tiga langkah yaitu : (a) Menginventarisir semua faktor yang mungkin atau dapat menjadi penyebab; (b) Berdasarkan penguasaan teoritis maupun pengalaman penelitian kemudian analis memilih faktor-faktor penyebab yang mungkin masuk; (c) Selanjutnya berdasarkan kekuatan logika, analis kemudian memilih faktor penyebab mana yang paling mungkin diubah dan dimodifikasi.

Berdasarkan hasil analisis terhadap permasalahan di lapangan ditemukan bahwa sesungguhnya dalam jangka panjang penigkatan pendapatan nelayan akan dapat dilakukan dengan cara pencapaian goal policy yaitu peningkatan akses terhadap modal, teknologi serta jaringan pemasaran dalam upaya mengurangi ketimpangan distibusi pendapatan nelayan (Pemilik, pengusaha dan buruh). Sehubungan dengan actionable causes (sebab dan faktor-faktor yang dapat ditindak lanjuti) tersebut, setelah dilakukan problem structuring melalui tahapan yang saling berhubungan, yaitu; pencarian masalah (problem search), pendefinisian masalah (problem definition), spesifikasi masalah (problem spesification) dan pengenalan masalah (problem sensing) sebagaimana dikemukakan oleh Dunn (1999), maka dapat di formulasikan suatu kebijakan (policy formulation) untuk menentukan alternatif kebijakan yang tepat dalam rangka meningkatkan pendapatan nelayan di Kabupaten Konawe. Berkaitan dengan hal tersebut, berdasarkan situasi problematis yang dihadapi oleh nelayan dan sebagai cara untuk mengatasi substantif problem yang dihadapi yaitu terbatasnya akses permodalan, akses teknologi serta rendahnya akses jaringan pemasaran hasil perikanan, maka diusulkan alternatif kebijakan sebagai berikut:

\section{Pembentukan dan pengembangan sistem jaringan pasar perikanan}

a. Tujuan umum kebijakan

Tujuan alternatif kebijakan ini adalah terbentuknya jaringan pasar perikanan hasil tangkapan nelayan yang kompetitif, tidak terikat oleh sistem tengkulak serta selain dapat memenuhi pasar lokal, hasil tangkap nelayan diharapkan juga dapat dipasarkan ke daerah-daerah kabupaten lainnya. Sehingga hal ini tentunya akan menjadi peluang bagi peningkatan nilai ekonomi nelayan, dan bukan hanya terpusat pada sekelompok saja (tengkulak). Untuk itu, mengingat pada umumnya aktivitas nelayan dilakukan secara berkelompok, maka pembinaan terhadap keberadaan mereka agar lebih ditingkatkan.

b. Fokus kebijakan

Hasil yang diharapkan dari alternatif kebijakan ini adalah:

$>$ Berkembang dan aktifnya peran kelompok-kelompok nelayan dan koperasi nelayan.

Diharapkan dengan berfungsinya kelompok-kelompok nelayan dan di adakannya koperasi nelayan, nelayan akan lebih memiliki bargaining position (posisi 
tawar) dalam menghadapi patron-client system tengkulak yang berlaku. Untuk itu, kelompok-kelompok nelayan dan koperasi yang ada diharapkan dalam waktu dekat agar segera mendapatkan bimbingan, pembinaan serta modal berupa dana untuk mendukung tercapainya tujuan tersebut.

Pembangunan pelabuhan perikanan atau pusat pendaratan ikan (PPI)

Ikan adalah komunitas yang cepat rusak (Perishable) dan karenanya harus dijaga kesegarannya sejak dari tempat penangkapan sampai dengan pemasaran serta seterusnya sampai pada tingkat pengolahan dan pada akhirnya sampai pada konsumen. Suatu hal yang sangat penting bagi daerah-daerah sentra produksi perikanan, yang kiranya diperlukan bagi nelayan adalah tersedianya pelabuhan perikanan sebagai sarana penunjang penangkapan ikan yang dilengkapai dengan fasilitas air bersih, cold storage, pabrik es, bengkel dan sebagainya sehingga dapat menunjang upaya peningkatan produksi, mutu dan mencapai harga jual yang memadai. Oleh karena itu untuk saat ini pemerintah Kabupaten Konawe hendaknya dapat membangun pelabuhan perikanan di daerah-daerah pinggir pantai sekitar kecamatan Soropia yang dapat dengan mudah dijangkau oleh para nelayan, sehingga pada akhirnya akan dapat dikembangkan menjadi suatu tempat pelelangan ikan.

\section{$>$ Pembangunan pasar pelelangan ikan}

Dengan telah berfungsinya kelompok nelayan dan adanya koperasi nelayan serta telah tersedianya pelabuhan perikanan dengan kelengkapan sarana dan prasarana penunjangnya, maka pada gilirannya akan tercipta suatu pasar yang lebih kompetitif bagi nelayan. Melalui sitem pelelangan yang baik dari kelompok dan koperasi nelayan yang ada serta adanya pembinaan, pengawasan dan arahan dari pemerintah, diharapkan tempat pelelangan ikan akan dapat memberikan kontribusinya baik bagi peningkatan pendapatan nelayan maupun bagi pendapatan daerah (PAD) melalui pajak dan retribusi di pasar ikan. Pembangunan pasar juga harus di fokuskan pada wilayah pesisir di kecamatan soropia yang dapat dengan mudah diakses.

\section{Pengembangan modernisasi teknologi alat tangkap nelayan}

a. Tujuan umum kebijakan

Tujuan alternatif kebijakan ini adalah peningkatan penerapan teknologi (penangkapan, penyimpanan dan pengolahan hasil ikan) khususnya bagi nelayan prasejahtera. Sehingga produktivitas mereka dari hasil penangkapan maupun semakin meningkat. Asumsi keberhasilan kebijakan ini adalah rendahnya resiko kegagalan penerapan teknologi, terjadinya peningkatan sumber daya manusia nelayan berupa pengetahuan dan keterampilan. Dengan adanya peningkatan pendapatan sebagai akibat semakin meningkatnya penerapan teknologi dan semakin tingginya tingkat pengetahuan nelayan terhadap teknologi alat tangkap, maka kedepannya nelayan tidak akan kesulitan lagi untuk beradaptasi dengan teknologi alat tangkap modern.

b. Fokus kebijakan

Hasil yang diharapkan dari alternatif kebijakan ini adalah :

Adanya program modernisasi/motorisasi alat tangkap perikanan 
Diperlukan adanya bantuan berupa alat-alat tangkap, baik perahu motor yang lebih modern dengan kapasitas lebih besar maupun alat tangkap lainnya seperti jaring. Sehingga diharapkan adanya perubahan penggunaan peralatan tangkap oleh nelayan dari yang sifatnya tradisional kepada teknologi tangkap yang lebih modern, yang penggunaannya tidak hanya sebatas pada perairan pantai atau terkonsentrasi pada satu wilayah perairan saja, akan tetapi dapat memperluas areal penangkapannya.

$>$ Adanya Penyuluhan teknologi dan pembinaan keterampilan

Untuk memahami kesulitankesulitan dan permasalahan yang dihadapi oleh para nelayan serta mencari jalan pemecahannya, penyuluhan teknologi dan pembinaan keterampilan terhadap nelayan sebagai upaya untuk memberdayakannya perlu lebih ditingkatkan sehingga diharapkan akan semakin meningkat kualitas maupun kuantitasnya hasil tangkap. Dengan begitu produktivitas kerja nelayan pun akan dapat meningkat sebagaimana yang diharapkan.

3. Pengembangan sistem permodalan bagi nelayan

a. Tujuan umum kebijakan

Tujuan alternatif kebijakan ini adalah peningkatan bantuan permodalan bagi nelayan miskin (buruh) yang selama ini terikat oleh patron-client system dengan tengkulak. Sehingga melalui bantuan permodalan ini diharapkan nelayan telah memiliki kemampuan untuk berusaha melaut sendiri ataupun membuka tambak. Asumsi keberhasilan alternatif kebijakan ini adalah nelayan dapat memanfaatkan bantuan untuk biaya operasional dan mampu mengembalikan pinjaman, serta bunga pinjaman yang rendah.

b. Fokus kebijakan

Pemerintah Kabupaten Konawe dapat mengimplementasikan program bantuan permodalan bagi nelayan dengan sumber dana dari dana perimbangan; baik berskala besar ataupun kecil, bersifat individual ataupun kelembagaan (kelompok nelayan) yang disalurkan melalui lembaga perkreditan (perbankan) pedesaan, dengan kemudahan birokrasi, bunga yang rendah namun tetap menggunakan kaidah-kaidah perbankan. Sehingga diharapkan alternatif kebijakan ini akan dapat melepaskan nelayan yang hidup dari hutang dan untuk hutang dari ketergantungannya dengan para tengkulak serta berfungsinya lembagalembaga kredit pedesaan seperti KUD dalam upaya menumbuhkan kemandirian dana dari masyarakat.

\section{Kesimpulan}

Pada umumnya nelayan di kabupaten konawe masih menggunakan sarana alat tangkap dengan kapasitas yang kurang memadai, baik dari jenis kapal maupun alat tangkap yang digunakan. Namun demikian hasil tangkap nelayan terus mengalami peningkatan setiap tahunnya, tetapi peningkatan hasil tangkap tersebut tidak berbanding lurus dengan peningkatan kesejahteraan nelayan di Kabupaten Konawe. Terdapat beberapa faktor yang mempengaruhi pendapatan nelayan, antara lain terbatasnya akses terhadap jaringan pemasaran hasil tangkap nelayan, terbatasnya teknologi alat penangkapan ikan, dan terbatasnya permodalan bagi nelayan untuk memenuhi biaya operasional penangkapan ikan. Sebagai 
upaya meningkatkan pendapatan nelayan di Kabupaten Konawe, maka ada beberapa alternatif kebijakan yang dapat dilaksanakan oleh Pemerintah Kabupaten Konawe dalam upaya meningkatkan pendapatan nelayan di Kabupaten Konawe, yaitu, pertama, pembentukan dan pengembangan sistem jaringan pemasaran melalui pengembangan dan peningkatan peran kelompok-kelompok nelayan dan koperasi nelayan; pembangunan pelabuhan perikanan atau pusat pendaratan ikan (PPI); dan pembangunan pasar pelelangan ikan. Kedua, pengembangan modernisasi teknologi bagi nelayan melalui program modernisasi/motorisasi alat tangkap perikanan; dan melakukan penyuluhan teknologi dan pembinaan keterampilan. Ketiga, pengembangan sistem permodalan bagi nelayan melalui program bantuan permodalan bagi nelayan dengan sumber dana dari dana perimbangan; baik berskala besar ataupun kecil, bersifat individual ataupun kelembagaan (kelompok nelayan) yang disalurkan melalui lembaga perkreditan (perbankan) pedesaan, dengan kemudahan birokrasi, bunga yang rendah namun tetap menggunakan kaidah-kaidah perbankan. Ketiga alternatif kebijakan yang direkomendasikan merupakan alternatif kebijakan yang bersifat complementary (saling mendukung dan melengkapi), sehingga perlu dilaksanakan secara sinergi pula.

\section{Daftar Pustaka}

BPS. (2017). Konawe Dalam Angka 2018. Jakarta: Badan Pusat Statistik.

Dunn, William, N. (1999). Pengantar Analisis Kebijakan Publik, Yogyakarta: Gadjah Mada university Press.

Fathoni, Aliza Noor. (2015). Strategi Kebijakan Pemerintah Daerah Dalam Upaya Peningkatan Pendapatan Nelayan. repository.iainpurwokerto.ac.id

Indriyani, Rachma; Satriyo, Ayub Torry; Sari, Diah Apriani Atika. (2017). Kebijakan Sekaya Maritim Dalam Rangka Peningkatan Kesejahteraan Nelayan Di Lampung Timur: Analisis Tantangan Dan Peluang. Jurnal Departemen Sosiologi FISIP UI Volume 24, hal. 1-14.

Karunia, R. Luki. (2009). Analisis Kebijakan Peningkatan Kesejahteraan Nelayan Kabupaten Administrasi Kepulauan Seribu. Disertasi (Dipublikasikan), Bogor: Sekolah Pascasarjana Institut Pertanian Bogor.

Mamentu, Michael. (2015). Implementasi Kebijakan Pemberdayaan Nelayan Tangkap Di Kota Manado (Studi Terhadap Pelaksanaan Program Usaha Mina Perdesaan Nelayan Tangkap Oleh Dinas Kelautan Dan Perikanan Provinsi Sulawesi Utara). Jurnal LPPM Bidang EkoSosBudKum. Vol. 2, No. 2, hal. 53-59.

Surkati, Ahmad. (2012). Otonomi Daerah sebagai Instrumen Pertumbuhan Kesejahteraan dan Peningkatan Kerjasama Antar daerah. Jurnal MIMBAR, Vol. XXVIII, No. 1, hal. 39-46. 
Winarno, Djoko Wahju. (2011). Kebijakan

Pemerintah Dalam Meningkatkan

Kesejahteraan Nelayan (Studi

Kebijakan Pemerintah pada

Nelayan Pantai Timur Pulau Jawa),

Disertasi (Dipublikasikan),

Yogyakarta: Fakultas Hukum

Universitas Gadjah Mada.

https://bunghatta.ac.id/artikel-73-

otonomi-daerah-dan-

pemberdayaan-nelayan.html.

Diakses pada Tanggal 11 Agustus

2018. 